\title{
Clonidine-containing Mucoadhesive Buccal Tablet
}

National Cancer Institute

\section{Source}

National Cancer Institute. Clonidine-containing Mucoadhesive Buccal Tablet. NCI

Thesaurus. Code C97329.

An extended release, proprietary mucoadhesive buccal tablet formulation containing the hydrochloride salt form of clonidine, the imidazoline derivative and adrenergic alpha 2 receptor agonist, with anti-inflammatory activity. Upon contact of the tablet with the buccal mucosa, clonidine binds to the adrenergic receptors on macrophages and lymphocytes and may reduce the release of pro-inflammatory mediators such as tumor necrosis factor alpha (TNFalpha). As a result, this agent may prevent chemoradiation therapy-induced mucositis. 